ISSN 1392-3196 / e-ISSN 2335-8947

Zemdirbyste-Agriculture, vol. 103, No. 2 (2016), p. 207-214

DOI $10.13080 / \mathrm{z}-\mathrm{a} .2016 .103 .027$

\title{
Cold acclimation efficiency of different Prunus and Fragaria species and cultivars in vitro
}

\author{
Rytis RUGIENIUS ${ }^{1,3}$, Lina ŠNIPAITIENE ${ }^{3}$, Gražina STANIENE ${ }^{1}$, \\ Jūrate Bronė ŠIKŠNIANIENE ${ }^{1}$, Perttu HAIMI ${ }^{1}$, Danas BANIULIS ${ }^{1,3}$, Birutė FRERCKS ${ }^{1}$, \\ Viktoras PRANCKIETIS ${ }^{2}$, Vanda LUKOŠEVIČIŪTÉ ${ }^{3}$, Vidmantas STANYS ${ }^{1,2}$ \\ ${ }^{1}$ Institute of Horticulture, Lithuanian Research Centre for Agriculture and Forestry \\ Kauno 30, Babtai, Kaunas distr., Lithuania \\ E-mail: r.rugienius@1sdi.lt \\ ${ }^{2}$ Aleksandras Stulginskis University \\ Studentų 11, Akademija, Kaunas distr., Lithuania \\ ${ }^{3}$ Vytautas Magnus University \\ K. Donelaičio 58, Kaunas, Lithuania
}

\begin{abstract}
Winter hardiness is one of the main traits affecting survival, productivity and cultivar choice for important horticultural plants in a temperate climatic zone. Given the complexity of the trait and the often fluctuating winter weather, extensive field testing over many years would be required to gain reliable results. Testing for cold tolerance under controlled conditions to grade genotypes has been used in several plant breeding programs to identify superior genotypes of different species. The aim of the present study was to investigate cold tolerance of microshoots of different genotypes of the genera Prunus and Fragaria after 7, 14, 28 and 56 days of cold acclimation, by measuring ion leakage and evaluating the critical temperature (CT50) after freezing in vitro. Genotypes of Rosacea family demonstrated distinct patterns of CT50 change during cold acclimation. Cold acclimation for 56 days decreased the CT50 value by $1.3-2.0^{\circ} \mathrm{C}$ for Prunus microshots and by $0.8-2.1^{\circ} \mathrm{C}$ for Fragaria microshoots in comparison to nonacclimated plants. The results of cold acclimation and freezing treatments of Rosacea family plants in vitro show that for maximal cold hardiness, acclimation for 56 days or longer is required. Sour cherry (Prunus cerasus) cv. 'Orkolija', garden strawberry (Fragaria $\times$ ananassa) cv. 'Melody', Virginia strawberry (F. virginiana) and musk strawberry (F. moschata) were the most winterhardy after 56 days' cold acclimation. The data obtained in the study can be used to improve breeding and cryopreservation technologies of Rosacea plants, and lay the foundation for identification of genes responsible for efficient cold acclimation and low temperature tolerance.
\end{abstract}

Key words: adaptivity, cultivars, fruit plants, genetic resources, low temperature, microshoots.

\section{Introduction}

Insufficient cold tolerance of fruit plants is one of the main factors in reducing yield and quality in the regions of temperate climate. Fluctuating temperatures and unstable snow cover increase the incidence of cold injury of the plants. Winter damage in Lithuania often causes $30-40 \%$ yield and plant losses of strawberry and up to $75 \%$ branch tissue damage of apple trees (Rugienius et al., 2009). Lack of winter hardiness limits the assortment of high quality pear, sour and sweet sherry cultivars. The survival of fruit plants during winter is affected by several factors or physiological responses, e.g., 1) growth cessation, 2) effective cold hardening in autumn, 3) sufficient minimal temperatures in January to complete the endodormancy phase and 4) the response to growth stimuli in periods of temporarily increased temperatures. With a range of biotic and abiotic factors contributing and interacting, disentangling the full story of winter survival has proven difficult (Davik et al.,
2013). However, low temperature stress per se is one of the most important aspects of winter survival. The cycles of freezing and thawing during wintertime have been shown to be particularly harmful to orchard plants (Sønsteby, Karhu, 2006). The genotypic variation of winter hardiness of Rosacea plants has been previously shown for octoploid Fragaria $\times$ ananassa and diploid $F$. vesca genotypes (Sønsteby, Heide, 2011), apple and pear (Rugienius et al., 2009). The production of cultivars with improved winter hardiness is a major objective for fruit breeding programs in Lithuania and other Nordic and East European countries. Improvement of cold tolerance is desirable for securing economic sustainability of the existing crops, and for expanding the growing regions of temperate fruit crops. Because strawberry and apple are representative species of the Rosaceae, the knowledge of genes involved in cold tolerance may be transferrable to the improvement of many of related crops, such as 
peaches, sweet and sour cherry, as well as blackberries and raspberries (Koehler et al., 2012). Additionally, the knowledge of properties of different Rosacea genotypes for CA and cold tolerance is important for securely maintaining Rosacea collections using cryopreservation and long- or midterm preservation in vitro.

Conventional breeding is time and space consuming and is hampered by seasonal variation of climatic conditions and other factors such as pests and diseases. The use of biotechnological methods allows year-round evaluations in controlled conditions, exhaustive study of biological mechanisms of adaptation, speeding up the breeding process and enlargement of genetic base by genetic engineering (Raia et al., 2011; Wisniewski et al., 2015). Biotechnological tools help to solve the critical problems of crop improvement for sustainable agriculture. Tissue culture technique has emerged as a feasible and cost-effective alternative tool for developing stress-tolerant plants in recent years. This technique can operate under controlled conditions with minimal environmental interaction, limited space and time can complement field selection, and has the potential for developing of stress-tolerant varieties using a low cost laboratory set up (Sakhanokho, Kelley, 2009; Verma et al., 2013).

Measuring electrolyte leakage is one of the most frequently used methods to assess plant tolerance in response to drought and low temperature (Davik et al., 2013). Abiotic stresses induce cell membrane injury, leading to the efflux of intracellular ions. Electrolyte leakage can reflect the change of ion exosmosis, and can be used as a measure of the level of cellular damage. There are several examples of selection for winter hardiness and cold tolerance investigations in vitro (Kushnarenko et al., 2009; Bilavčík et al., 2012). A technology of screening cold hardy strawberry seedlings in early development stage has been developed (Rugienius et al., 2009). Accumulation of dehydrins and other metabolites as well as the expression of cold induced genes during cold acclimation in fruit plants has been previously investigated (Zalunskaite et al., 2008; Lukoševičiūtè et al., 2009; Baniulis et al., 2012). The aim of the present study was to investigate cold tolerance of microshoots of different genotypes of genus Prunus and Fragaria after periods of cold acclimation by evaluating the ion leakage and by calculating the critical temperature (CT50) after freezing in vitro. However, this study is the first time the cold acclimation efficiency in vitro and the CT50 data have been determined in controlled conditions for several genera of Rosacea family plants. The data obtained in the study help to ascertain the duration of cold acclimation sufficient for maximal cold tolerance, as well as to find commonalities and differences in responses to cold acclimation and hardening among different Rosacea species.

\section{Materials and methods}

Microshoots of sour cherry (Prunus cerasus) cvs. 'Molodiožnaja' and 'Orkolija', sweet cherry (P. avium) cvs. 'Merchant', 'Jurgita' and 'Vietinè rūgščioji', wild strawberry (Fragaria vesca), musk strawberry (F. moschata), Virginia strawberry $(F$. virginiana) and garden strawberry $(F . \times$ ananassa $)$ cvs. 'Elsanta', 'Melody', 'Venta', 'Dangè' and 'Holiday' were used in the study. The microshoots were cultivated in glass flasks in vitro on the solid Murashige and Skoog (1962) medium containing $0.75 \mathrm{mg} \mathrm{l}^{-1}$ 6-benzylaminopurine (BAP) and $3.0 \%$ sucrose, $0.8 \%$ agar, $\mathrm{pH} 5.8$ in growing chamber under $22 \pm 3^{\circ} \mathrm{C}$ temperature using $50-150 \mu \mathrm{mol} \mathrm{m} \mathrm{m}^{-2} \mathrm{~s}^{-1}$ intensity light fluorescent lamps with $16 / 8 \mathrm{~h}$ a day/night photoperiod. Microshoots were cold acclimated in $4 \pm$ $2^{\circ} \mathrm{C}$ temperature for $7,14,28$ and 56 days with $8 / 16 \mathrm{~h}$ a day/night photoperiod, using $25-50 \mu \mathrm{mol} \mathrm{m}^{-2} \mathrm{~s}^{-1}$ intensity light. Freezing was performed in the climate chamber LT36VL (Percival Scientific, USA) by decreasing the temperature at the speed of $1{ }^{\circ} \mathrm{C} \mathrm{h}^{-1}$ at the $-5--10^{\circ} \mathrm{C}$ temperature interval. Cold injury of microshoots and leaf tissues was evaluated based on ion leakage using a conductivity meter B250, QIS, (ProLine, Netherlands).

After freezing, the samples were thawed and incubated at $4{ }^{\circ} \mathrm{C}$ in $10 \mathrm{ml}$ deionized water for 24 hours. Ion leakage measurement of the same sample was performed twice - after incubation and after autoclaving. Relative electrolyte leakage was determined by normalization in respect to results of not treated control and frozen at the lowest temperature $\left(-20^{\circ} \mathrm{C}, 6\right.$ hours $)$ samples. Relative electrolyte leakage at temperature $\mathrm{T}: \mathrm{RELT}=(\mathrm{ELT} / \mathrm{ELAUTOCL}) \times 100 \%$. Index of injury at temperature ELCONTR) / (100 - RELCONTR $)] \times 100 \%$. Percentage-adjusted injury at temperature $\mathrm{T}: \mathrm{NIT}=$ (IT/ITLOWEST) $\times 100 \%$, where ELT is sample electrolyte leakage after exposure to temperature T, ELAUTOCL - sample electrolyte leakage after autoclaving, RELCONTR - the mean relative electrolyte leakage of control samples, ITLOWEST - the mean index of injury of samples exposed to the lowest test temperature. To calculate the electrolyte leakage corresponding to $50 \%$ mortality rate of microshoots, injury score was measured and viable microshoots were counted after freezing in different temperatures. Critical electrolyte leakage was considered as arithmetic average among electrolyte leakage results obtained at the temperature, where all frozen microshoots die and electrolyte leakage after freezing at the temperature where all microshoots survive. According to the data of our investigations, critical electrolyte leakage for Fragaria and Prunus was 65\% and $62 \%$, respectively. Temperature range of microshoot mortality was $6-14^{\circ} \mathrm{C}$ for Fragaria and $8-11^{\circ} \mathrm{C}$ for Prunus genotypes. Critical temperature (CT50) was calculated using linear regression $\bar{y}=a+b \bar{x}$, where $a=\bar{y}-b \bar{x}$, $b=\sum(x-\bar{x})(y-\hat{y}) / \sum(x-\bar{x})^{2}, \bar{x}-$ electrolyte leakage $\%, \bar{y}$ - temperature, $x$ and $y$ - averages. Average of 10 repetitions and error of standard deviation are presented. $M S$ Excel 2013 (Microsoft, USA) was used for calculations.

\section{Results}

Our results show that non-acclimated Prunus cultivars involved in the study (two sour cherry and three 
sweet cherry cultivars) did not demonstrate significant differences of freezing tolerance (Fig. 1). Small change of CT50 values was observed after 7 days of cold acclimation. After 14 days of cold acclimation, CT50 of cvs. 'Molodiožnaja' and 'Vietinè rūgščioji' did not change. The CT50 value of the remaining three cultivars was slightly decreased. After 28 and 56 days of cold acclimation, CT50 of Prunus cultivars decreased gradually but for cv. 'Orkolija' this decrease was significantly more pronounced as compared to the remaining cultivars, especially after 28 days of cold acclimation $\left(1.3^{\circ} \mathrm{C}\right.$ as compared to 14 day cold acclimation plants). Compared to non-acclimated microshoots, the CT50 decrease after 56 days of cold acclimation was on average $2.0^{\circ} \mathrm{C}$ for $\mathrm{cv}$. 'Orkolija' and $1.3-1.6^{\circ} \mathrm{C}$ for other cultivars.

It was established that in agreement with the results obtained for the Prunus cultivars, CT50 value did not differ significantly for non-acclimated and cold acclimated for 7 days Fragaria microshoots (Fig. 2).

After 14, 28 and 56 days of cold acclimation CT50 of the Fragaria cultivars decreased gradually and the extent of the decrease was genotype dependent. Variation of the CT50 value among the cultivars increased also gradually. After 14 days of cold acclimation, the amount of this variation was $0.7^{\circ} \mathrm{C}$, after 28 days $0.9^{\circ} \mathrm{C}$, after 56 days $-1.6^{\circ} \mathrm{C}$. Significant decrease of CT50 as compared to non-acclimated microshoots was observed for F. moschata and $F$. × ananasa cv. 'Dangè' microshoots after 14 days of cold acclimation. After 28 days of cold acclimation only microshooots of cvs. 'Elsanta' and 'Holiday' remained at the same level of CT50 as non-acclimated microshoots. The value of other treated cultivars decreased significantly, especially for cv. 'Venta' (almost $1.0^{\circ} \mathrm{C}$ comparing 14 days cold acclimation plants). The largest decrease of CT50 value after 56 of cold acclimation $\left(1.5^{\circ} \mathrm{C}\right.$ comparing 28 days cold acclimation plants) was observed for cv. 'Melody' microshoots. After 56 days of cold acclimation, the CT50 value decrease as compared to non-acclimated microshoots was from $0.8^{\circ} \mathrm{C}$ ('Elsanta', 'Holiday') to $2.1^{\circ} \mathrm{C}$ ('Melody').
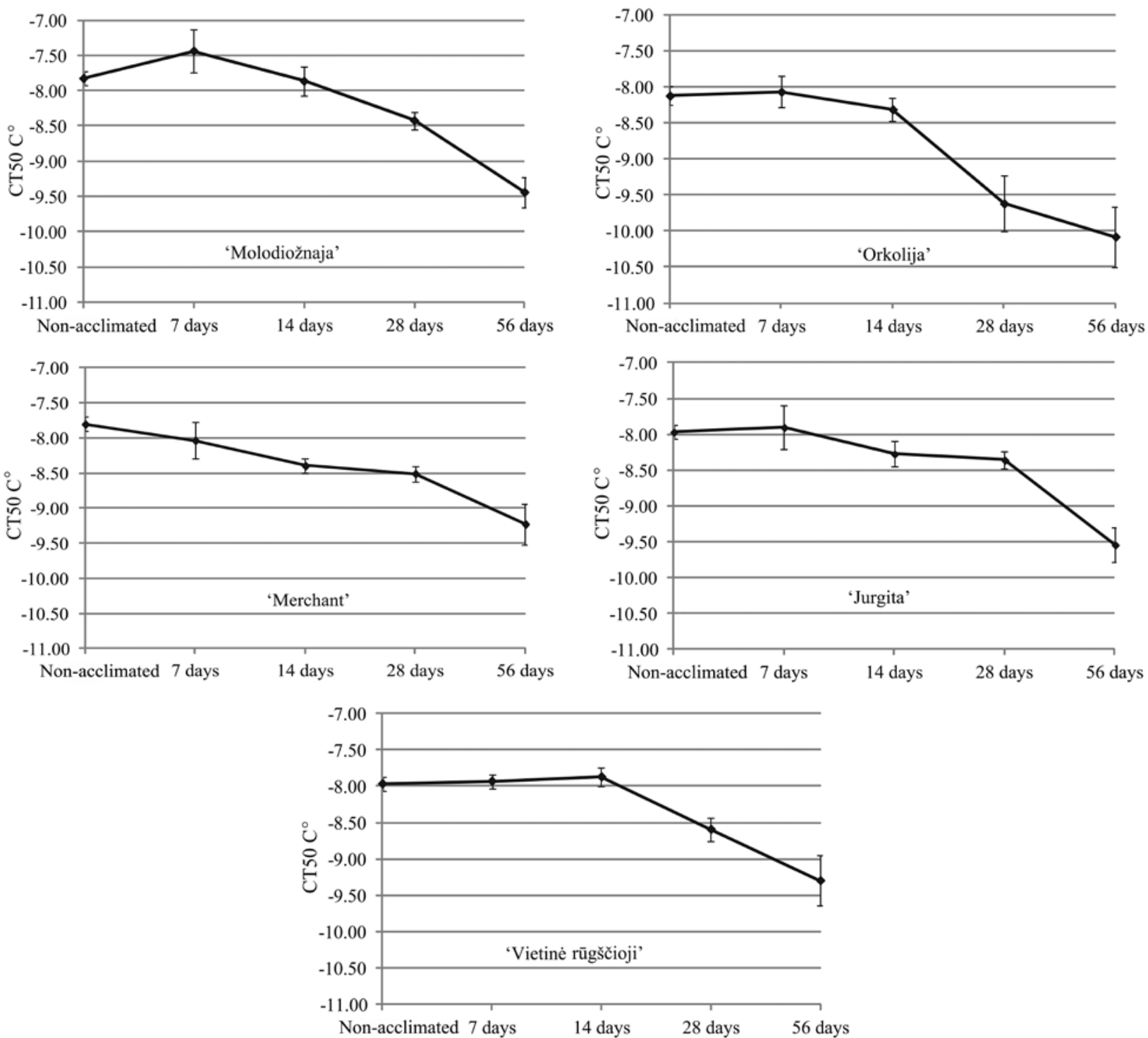

Figure 1. Change of critical temperature (CT50) for microshoots of Prunus during a 56-day cold acclimation period 

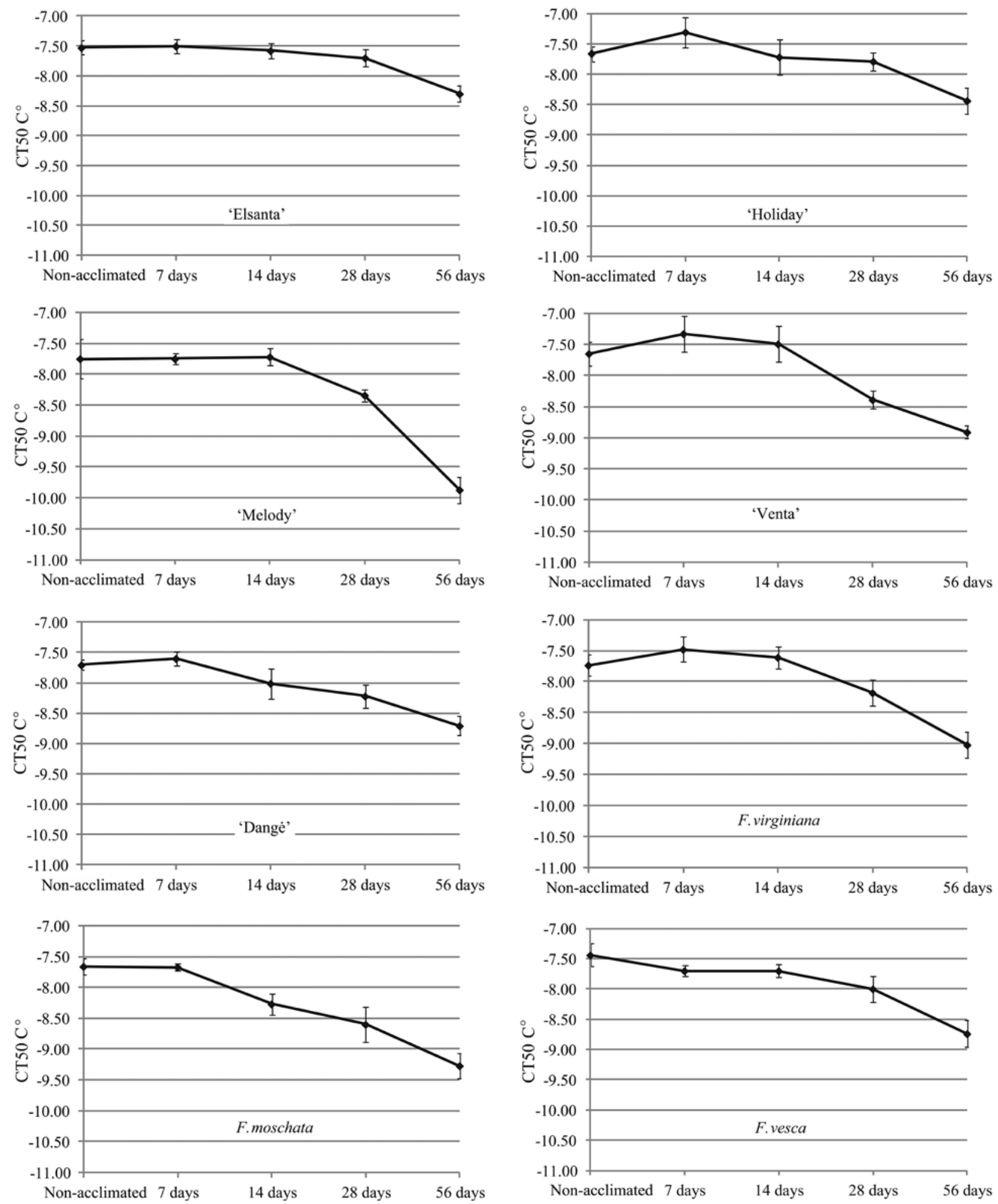

Figure 2. Change of critical temperature (CT50) for microshoots of Fragaria sp. during a 56-day cold acclimation period

\section{Discussion}

The results of our study show that CT50 value corresponding to cold tolerance of the selected Prunus and Fragaria microshoots varied depending on the genotype and the duration of cold acclimation. After 28 and 56 days of cold acclimation of Prunus cultivars, CT50 decrease for cv. 'Orkolija' was significantly more prominent as compared to the remaining cultivars. According to Stepulaitienè et al. (2013), cv. 'Orkolija' was the latest blooming cultivar among the investigated sour cherry cultivars - for full bloom it required the highest sum of active temperatures. In contrast to other investigated cultivars, cv. 'Orkolija' was the most susceptible to spring frost during the phase of full bloom, whereas the 
other cultivars were most susceptible during the fruit germ phenological phase. The trait of the late blooming could be associated with deeper and more prolonged rest period. These results were in agreement with our data showing that microshoots of cv. 'Orkolija' reached the highest cold tolerance. Such results supported the idea that the level of cold acclimation was directly related to the depth of the rest period.

It was revealed that after 28 and 56 days of cold acclimation in vitro, $F . \times$ ananassa cvs. 'Melody' and 'Venta', and also $F$. virginiana and $F$. moshata had the lowest CT50 values. It is known from previous studies that wild Fragaria species and some strawberry cultivars ('Melody' and 'Venta' among them) are more winter and cold hardy in vivo and in vitro (Lukoševičiūtè et al., 2012). These results confirm the suggestion of Palonen and Buszard (1997) that correspondence of in vitro and in vivo freezing results for strawberry can only be obtained after appropriate cold acclimation.

Additional insights about cold acclimation and freezing tolerance of plants of Rosaceae family could be revealed when the results of the presented study were compared to the previously published results from our laboratory (Rugienius et al., 2016) on cold acclimation and freezing tolerance of microshoots of Malus and Pyrus sp. A total of twenty three genotypes were used in the studies. Assessment of cold tolerance of nonacclimated microshoots revealed that the mean CT50 value $\left(7.7^{\circ} \mathrm{C}\right)$ of all the tested genera was quite similar and varied only by $0.4^{\circ} \mathrm{C}$. The amplitude of variation for all genera, except Malus, was relatively low and reached $0.3-0.7^{\circ} \mathrm{C}$, demonstrating that cold tolerance did not differ significantly among the non-acclimated microshoots. Malus sp. differed from the other three species by comparatively high variation of the CT50 value and according to the results of previous study (Rugienius et al., 2016); three groups of Malus genotypes could be distinguished based on the results obtained with the nonacclimated microshoots. $M$. prunifolia microshoots were the most winterhardy. Surprisingly, the highest CT50 value $\left(-6.8 \pm 0.3^{\circ} \mathrm{C}\right)$ was measured from non-acclimated microshoots of the local Lithuanian cv. 'Auksis'. This cultivar was previously described as winterhardy in Lithuania (Tuinyla et al., 1990). The third group consisted of the other four Malus genotypes with CT50 value equal aprox. $-7.7^{\circ} \mathrm{C}$. This is close to the temperature $-7^{\circ} \mathrm{C}$ that has been reported by Mathers and Stushnoff (2005) as the temperature which non-acclimated apple seedlings could survive during the freezing test under controlled conditions in vivo.

Our results show that cold acclimation for 7 days did not change the CT50 value of investigated genera (Table), suggesting that 7 days of cold acclimation is not sufficient to improve the cold tolerance of Rosacea family microshoots. Cold acclimation for 14, 28 and 56 days decreased the mean CT50 value by $0.2,0.6$ and 1.3, respectively, suggesting that CT50 decrease was proportional to the duration of cold acclimation treatment. After acclimation for 56 days, CT50 value decreased as compared to non-acclimated microshoots from $1.1^{\circ} \mathrm{C}$ (Pyrus) to $1.6^{\circ} \mathrm{C}$ (Prunus). The amount of variation of the CT50 value also changed depending on duration of cold acclimation treatment, but this change was not the same for different Rosacea genera. Higher variation indicated larger differences among the genotypes and made it possible to differentiate them according to their cold tolerance. After shorter durations of cold acclimation treatment, value of the CT50 amplitude did not differ from non-acclimated plants. Despite the slight mean decrease of CT50, genotype differentiation of Rosacea microshoots, cold acclimated for 14 days, was not statistically significant. Especially large increase of the CT50 value was observed for Prunus and Malus microshoots after 28 days of cold acclimation. The maximum CT50 value was achieved by Fragaria microshoots after 56 days of cold acclimation, whereas for the rest of Rosacea species, the maximum was reached after 28 days of cold acclimation. Since the relationship among the levels of cold tolerance for the genotypes of Malus, Pyrus and Fragaria sp. observed after 28 days of cold acclimation was different after 56 days of cold acclimation treatment, it could be suggested that 56 days was the optimal cold acclimation duration for evaluating the cold tolerance of genotypes. Such change did not occur for Prunus genotypes. Therefore, sufficient cold acclimation duration for the genotype differentiation was 28 days. The highest amplitude of CT50 variation was determined for non-acclimated Malus genotypes. However, the relationship among levels of cold tolerance established by the in vitro freezing did not correspond to known winter hardiness under field conditions - cv. 'Auksis' was more winterhardy than cvs. 'Gala' and

Table. Critical temperature (CT50) and amplitude of its variation (shown in the brackets) among different Rosacea genera for non-acclimated microshoots and for microshoots after 7, 14, 28 and 56 days of cold acclimation treatment

\begin{tabular}{ccccccc}
\hline \multirow{2}{*}{ Genus } & \multirow{2}{*}{$\begin{array}{c}\text { Number of } \\
\text { genotypes }\end{array}$} & \multicolumn{5}{c}{ Cold acclimation duration } \\
\cline { 3 - 6 } & & non-acclimated & 7 days & 14 days & 28 days & 56 days \\
\hline Malus* & 6 & $-7.6(1.7)$ & $-7.6(1.1)$ & $-7.8(0.8)$ & $-8.1(1.4)$ & $-8.8(1.4)$ \\
Pyrus* & 4 & $-7.5(0.3)$ & $-7.7(0.5)$ & $-7.9(0.5)$ & $-8.3(0.6)$ & $-8.6(0.6)$ \\
Prunus & 5 & $-7.9(0.5)$ & $-7.9(0.8)$ & $-8.1(0.7)$ & $-8.7(1.5)$ & $-9.5(1.1)$ \\
Fragaria & 8 & $-7.7(0.7)$ & $-7.5(0.6)$ & $-7.8(0.9)$ & $-8.2(1.1)$ & $-8.9(1.7)$ \\
\hline Mean & & $-7.7(0.8)$ & $-7.7(0.8)$ & $-7.9(0.7)$ & $-8.3(1.1)$ & $-9.0(1.2)$ \\
\hline
\end{tabular}

* - results of previous cold tolerance investigations Rugienius et al. (2016) 
'Golden Delicious' under field conditions (Rugienius et al., 2009). Such correspondence between in vitro and in vivo results for investigated Rosacea species (except Prunus) was obtained only after 56 days of cold acclimation.

According to Bilavčík et al. (2012), in vitro apple plantlets were the most cold tolerant after 7 weeks of cold-treatment, 1 week before entering endodormancy. After 8 weeks, the cold tolerance decreased, and after 20 weeks of cold acclimation it was on the level of nontreated control plants. At the end of the cultivation, the cold tolerance was even lower than in the control plants (Bilavčík et al., 2012). The cold tolerance in these experiments was higher than that obtained by Kushnarenko et al. (2009), who showed that plantlets had the lowest lethal temperature (LT50) values after 1-3 weeks of cold acclimation under short day ( $8 \mathrm{~h}$ light) at $2^{\circ} \mathrm{C}$, followed by a $48 \mathrm{~h}$ period at $-3^{\circ} \mathrm{C}$. Sedlák et al. (2001) obtained maximal cold tolerance of apple and pear in vitro after $4-5$ weeks of hardening at $4^{\circ} \mathrm{C}$ with long day lengths (16 light/8 dark). The in vitro apple plantlets reached cold-hardened state after shorter period ( 3 weeks) of the cold acclimation at $5^{\circ} \mathrm{C}$ (Halmagyi et al., 2010). Three weeks of cold hardening using alternating temperature can be recommended as a standard protocol for Malus germplasm cryopreservation (Kushnarenko et al., 2009). Before freezing studies, diploid strawberry plants were acclimated for 6 weeks at $2^{\circ} \mathrm{C}$ and 10 -h photoperiod in vitro (Davik et al., 2013). A study of influence of cold hardening on strawberries showed that 9 weeks of cold hardening provided the best results, while longer chilling treatment of plantlets resulted in weak growth (Borkowska, Michalczuk, 2000). Two weeks before assessing of endodormancy in the $8^{\text {th }}$ week, leaves of apple plantlets ceased growing, became yellowish, brownish, and went down. This was apparently connected with entering the endodormant period, for which the increased production of abscisic acid (ABA), the main hormone controlling endodormancy and the associated autumn leaf fall in plants, is typical (Arora et al., 2003; Bilavčík et al., 2012). Changes in the expression of hundreds of genes, total reconfiguration of metabolite profiles and accumulation of specific compounds during cold acclimation have been demonstrated in different plants (Kaplan et al., 2007; Rohloff et al., 2012). It was revealed that alcohol dehydrogenase, dehydrins, and galactinol show great potential to serve as biomarkers for cold tolerance of different Rosacea plants (Baniulis et al., 2012; Koehler et al., 2012; Davik et al., 2013). The data of our study corresponded well with the results obtained by other researchers. Some differences in the results might arise mainly due to the variations of day length and temperature regimes of cold acclimation procedure.

It is notable that some of the genotypes of different Rosacea species showed stability of CT50 value up to 28 days of cold acclimation treatment. We suppose that dynamics of CT50 change reflects sensitivity to low above zero temperatures and efficiency of cold acclimation. Analysis of profile of CT50 change after different durations of cold acclimation observed in our study revealed that the pattern of the CT50 dynamics was specific for most of Rosacea genotypes. Nevertheless, some tendencies were observed. For example, CT50 value for some genotypes that are winterhardy under field conditions, such as Fragaria $\times$ ananassa cvs. 'Venta' and 'Melody', as well as $F$. vesca N3, F. virginiana started to decrease after 14 days of cold acclimation, whereas for insufficiently winterhardy $F$. $\times$ ananassa cvs. 'Holiday' and 'Elsanta', the decrease was observed after 28 days of cold acclimation. In contrast, winterhardy genotypes of M. domestica cv. 'Popierinis', M. platicarpa, P. cerasus cvs. 'Vietinè rūgščioji', 'Orkolija' retained their CT50 at the same level as non-acclimated plants up to 14-28 days, whereas CT50 for less winterhardy $M$. domestica cvs. 'Gala' and 'Golden Delicious' and P. avium cv. 'Merchant' started to decrease after 7 days of cold acclimation. It was observed that the CT50 value of Malus ('Auksis'), Fragaria (F. moschata 'Dangè'), Pyrus (all except P. pyraster), Prunus ('Molodiožnaja') microshoots decreased consistently during the cold acclimation treatment. It illustrates that despite some similarities in cold acclimation dynamics among different Rosacea genera and species, specific genotypes might use different cold acclimation strategies and possibly different mechanisms. Some homological orders might exist in Rasacea family in this instance. Therefore, the variation in cold tolerance among the cultivars and species within genus often was larger than the variation among the different Rosacea genera.

\section{Conclusions}

1. Different genotypes in Rosacea family demonstrated distinct patterns of critical temperature (CT50) change during cold acclimation. It was found that cold acclimation for 56 days decreased CT50 value by $1.3-2.0^{\circ} \mathrm{C}$ for Prunus microshots and $0.8-2.1{ }^{\circ} \mathrm{C}$ for Fragaria microshoots as compared to non-acclimated plants.

2. The results of cold acclimation and freezing treatment of plants of Rosacea family in vitro showed that cold acclimation for 56 days or longer was required to achieve maximum cold hardiness. P. cerasus cv. 'Orkolija' and $F$. × ananassa cv. 'Melody', $F$. virginiana and $F$. moschata were the most cold tolerant after 56 days of cold acclimation. It was established that cold acclimation duration not less than 28 and 56 days was required for reliable genotype differentiation of Prunus and Fragaria genotypes, respectively.

\section{Acknowledgements}

The research was funded by the Research Council of Lithuania, grant No. MIP-54/2013.

Received 12102015

Accepted 21032016 


\section{References}

Arora R., Rowland L. J., Tanino K. 2003. Induction and release of bud dormancy in woody perennials: a science comes of age. HortScience, 38: 911-921

Baniulis D., Stepulaitienè I., Lukoševičiūtė V., Blažytė A., Stanys V., Rugienius R., Sasnauskas A. 2012. Accumulation of dehidrin-like proteins in pear (Pyrus communis L.) microshoots during cold acclimation. ZemdirbysteAgriculture, 99 (3): 293-298

Bilavčík A., Zámečník J., Grospietsch M., Faltus M., Jadrná P. 2012. Dormancy development during cold hardening of in vitro cultured Malus domestica Borkh. plants in relation to their frost tolerance and cryotolerance. Trees, 26: $1181-1192$ http://dx.doi.org/10.1007/s00468-012-0694-7

Borkowska B., Michalczuk L. 2000. Characteristics of the dormancy in in vitro propagated strawberry fruit plants. Zeszyty Problemowe Postepow Nauk Rolniczych, 473: 39-45 (in Polish)

Davik J., Koehler G., From B., Torp T., Rohloff J., Eidem P., Wilson R. C., Sønsteby A., Randall S. K., Alsheikh M. 2013. Dehydrin, alcohol dehydrogenase, and central metabolite levels are associated with cold tolerance in diploid strawberry (Fragaria spp.). Planta, 237 (1): 265-77 http://dx.doi.org/10.1007/s00425-012-1771-2

Halmagyi A., Valimareanu S., Coste A., Deliu C., Isac V. 2010. Cryopreservation of Malus shoot tips and subsequent plant regeneration. Romanian Biotechnology Letters, 15 (1): 79-85

Kaplan F., Kopka J., Sung D. Y., Zhao W., Popp M., Porat R., Guy C. L. 2007. Transcript and metabolite profiling during cold acclimation of Arabidopsis reveals an intricate relationship of coldregulated gene expression with modifications in metabolite content. Plant Journal, 50: 967-981 http://dx.doi.org/10.1111/j.1365-313X.2007.03100.x

Koehler G., Wilson R. C., Goodpaster J. V., Sønsteby A., Lai X., Witzmann F. A., You J. S., Rohloff J., Randall S. K., Alsheikh M. 2012. Proteomic study of low-temperature responses in strawberry cultivars (Fragaria $\times$ ananassa) that differ in cold tolerance. Plant Physiology, 159 (4): 1787-805 http://dx.doi.org/10.1104/pp.112.198267

Kushnarenko S. V., Romadanova N. V., Reed B. M. 2009. Cold acclimatization improves regrowth of cryopreserved apple shoot tips. Cryo Letters, 30 (1): 47-54

Lukoševičiūtė V., Rugienius R., Zalunskaitė I., Sasnauskas A., Stanys V. 2009. Strawberry cold hardening investigations in vitro. Acta Horticulturae, 842: 789-792 http://dx.doi.org/10.17660/ActaHortic.2009.842.173

Lukoševičiūtė V., Rugienius R., Stanienė G., Blažytė A., Gelvonauskienė D., Bendokas V., Gelvonauskis B., Sasnauskas A., Stanys V., Bobinas C̆. 2012. Low temperature storage of Fragaria sp. and Pyrus sp. genetic resources in vitro. Zemdirbyste-Agriculture, 99 (2): 125-130

Mathers H. M., Stushnoff C. 2005. Screening Malus seedlings for cold hardiness. Hortscience, 40 (2): 318-322

Murashige T., Skoog F. 1962. A revised medium for rapid growth and bio-assays with tobacco tissue cultures. Physiologia Plantarum, 15 (3): 473-497 http://dx.doi.org/10.1111/j.1399-3054.1962.tb08052.x

Palonen P., Buszard D. 1997. Screening strawberry cultivars for cold hardiness in vitro. Acta Horticulturae, 439: 217-220 http://dx.doi.org/10.17660/ActaHortic.1997.439.31
Raia M. K., Kaliaa R. K., Singha R., Gangolaa M. P., Dhawana A. K. 2011. Developing stress tolerant plants through in vitro selection - an overview of the recent progress. Environmental and Experimental Botany, 71: 89-98

http://dx.doi.org/10.1016/j.envexpbot.2010.10.021

Rohloff J., Kopka J., Erban A., Winge P., Wilson R. C., Bones A. M., Davik J., Randall S. K., Alsheikh M. K. 2012. Metabolite profiling reveals novel multi-level cold responses in the diploid model Fragaria vesca (woodland strawberry). Phytochemistry, 77: 99-109 http://dx.doi.org/10.1016/j.phytochem.2012.01.024

Rugienius R., Siksnianas T., Gelvonauskiene D., Staniene G., Sasnauskas A., Zalunskaite I., Stanys V. 2009. Evaluation of genetic resources of fruit crops as donors of cold and disease tolerance in Lithuania. Acta Horticulturae, 825: $117-124$

http://dx.doi.org/10.17660/ActaHortic.2009.825.14

Rugienius R., Stanienė G., Gelvonauskienė D., Stepulaitienė I., Haimi P., Baniulis D., Stanys V. 2016. Assessment of cold hardiness of apple and pear in vitro. Acta Horticulturae (in press)

Sakhanokho H. F., Kelley R. Y. 2009. Influence of salicylic acid on in vitro propagation and salt tolerance in Hibiscus acetosella and Hibiscus moscheutos (cv. 'Luna Red'). African Journal of Biotechnology, 8: 1474-1481

Sedlák J., Paprštein F., Bilavcík A., Zámecník J. 2001. Adaptation of apple and pear plants to in vitro conditions and to low temperature. Acta Horticulturae, 560: 457-460 http://dx.doi.org/10.17660/ActaHortic.2001.560.90

Sønsteby A., Heide O. M. 2011. Environmental regulation of dormancy and frost hardiness in Norwegian populations of wood strawberry (Fragaria vesca L.). European Journal of Plant Science and Biotechnology, 5 (spec. iss. 1): 42-48

Sønsteby A., Karhu S. 2006. Strawberry production, growth and development in northern climates. International Journal of Fruit Science, 5 (1): 107-114

http://dx.doi.org/10.1300/J492v05n01 10

Stepulaitienė I., ŽebrauskienėA., Stanys V. 2013. Frost tolerance is associated with development of sour cherry (Prunus cerasus L.) generative buds. Zemdirbyste-Agriculture, 100 (2): $175-178$ http://dx.doi.org/10.13080/z-a.2013.100.022

Tuinyla V., Lukoševičius A., Bandaravičius A. 1990. Pomology of Lithuania. T1. Apples and pears. Vilnius, Lithuania, 333 p. (in Lithuanian)

Verma D., Ansari M. W., Agrawal G. K., Rakwal R., Shukla A., Tuteja N. 2013. In vitro selection and field responses of somaclonal variant plants of rice cv. PR113 for drought tolerance. Plant Signalling and Behavior, 8 (4): e23519 doi: $10.4161 /$ psb.23519

http://dx.doi.org/10.4161/psb.23519

Wisniewski M., Norelli J., Artlip T. 2015. Overexpression of a peach $\mathrm{CBF}$ gene in apple: a model for understanding the integration of growth, dormancy, and cold hardiness in woody plants. Frontiers in Plant Science, 6: 85 doi: $10.3389 /$ fpls. 2015.00085 http://dx.doi.org/10.3389/fpls.2015.00085

Zalunskaitė I., Rugienius R., Vinskienė J., Bendokas V., Gelvonauskiene D., Stanys V. 2008. Expression of COR gene homologues in different plants during cold acclimation. Biologija, 54: 33-35 http://dx.doi.org/10.2478/v10054-008-0007-7 
ISSN 1392-3196 / e-ISSN 2335-8947

Zemdirbyste-Agriculture, vol. 103, No. 2 (2016), p. 207-214

DOI 10.13080/z-a.2016.103.027

\title{
İvairiụ Prunus ir Fragaria rūšių bei veislių augalụ užsigrūdinimo in vitro efektyvumas
}

\author{
R. Rugienius ${ }^{1,3}$, L. Šnipaitiene ${ }^{3}$, G. Stanienè $\dot{1}^{1}$, J. B. Šikšnianiené ${ }^{1}$, P. Haimi ${ }^{1}$, D. Baniulis ${ }^{1,3}$, \\ B. Frercks ${ }^{1}$, V. Pranckietis ${ }^{2}$, V. Lukoševičiūtè ${ }^{3}$, V. Stanys ${ }^{1,2}$ \\ ${ }^{1}$ Lietuvos agrarinių ir miškų mokslų centro Sodininkystès ir daržininkystès institutas \\ ${ }^{2}$ Aleksandro Stulginskio universitetas, Lietuva \\ ${ }^{3}$ Vytauto Didžiojo universitetas, Lietuva
}

\section{Santrauka}

Ištvermingumas žiemą yra vienas svarbiausių veiksnių, lemiančių sodininkystei svarbių augalų išgyvenamumą ir veislių pasirinkimą vidutinio klimato juostoje. Dèl šio požymio kompleksiškumo dažnai besikeičiančių orų žiemojimo metu ekstensyvi atranka lauko sąlygomis, siekiant gauti patikimus rezultatus, reikalauja daugelio metų tyrimų. Siekiant diferencijuoti ịvairių rūšių genotipus ir atrinkti atspariausius šalčiui, ịvairiose selekcijos programose naudojamas atsparumo šalčiui tyrimas kontroliuojamomis sąlygomis. Tyrimo tikslas - ištirti Prunus ir Fragaria genčių mikroaugalų atsparumą šalčiui po 7, 14, 28 ir 56 dienų grūdinimo žemoje teigiamoje temperatūroje, ịvertinant jonų išplovimą ir apskaičiuojant kritinę temperatūrą (CT50) po šaldymo in vitro. Tyrimo metu nustatyta, kad erškètinių (Rosacea) šeimos skirtingų genotipų augalų CT50 kitimo pobūdis grūdinimo metu buvo nevienodas. Nustatyta, kad 56 dienų trukmès grūdinimas, lyginant su negrūdintais augalais, Prunus mikroūglių CT50 vertę sumažino $1,3-2,0^{\circ} \mathrm{C}$, Fragaria $-0,8-2,1^{\circ} \mathrm{C}$. Erškètinių šeimos augalų grūdinimo ir šaldymo rezultatai rodo, kad norint pasiekti maksimalų atsparumą šalčiui, reikia grūdinti ne trumpiau nei 56 dienas. Po 56 dienų grūdinimo šalčiui atspariausios in vitro buvo paprastosios vyšnios (P. cerasus) veislè 'Orkolija', daržinès braškès $(F$. $\times$ ananassa) veislè 'Melody' ir virgininè žemuogè (F. virginiana) bei aukštoji žemuogè (F. moschata). Grūdinimo trukmè esminei Prunus genotipų diferenciacijai yra ne mažesnè nei 28 dienos, o Malus, Pyrus ir Fragaria - 56 dienos. Tyrimo metu gauti duomenys vertingi tobulinant erškètinių šeimos augalų selekcijos ir saugojimo skysto azoto (krio) temperatūroje technologijas, sudaro prielaidas identifikuoti genus, lemiančius efektyvų grūdinimąsi ir atsparumą šalčiui.

Reikšminiai žodžiai: adaptyvumas, genetiniai resursai, mikroaugalai, šaldymas, užsigrūdinimas, vaisiniai augalai, veislès.

Please use the following format when citing the article:

R. Rugienius, L. Šnipaitienè, G. Stanienè, J. B. Šikšnianienè, P. Haimi, D. Baniulis, B. Frercks, V. Pranckietis, V.Lukoševičiūtè, V. Stanys. 2016. Cold acclimation efficiency of different Prunus and Fragaria species and cultivars in vitro. Zemdirbyste-Agriculture, 103 (2): 207-214 DOI 10.13080/z-a.2016.103.027 